\title{
Evaluation of The Residents' Perspective on Their Neighbourhood in the Context of Urban Transformation: The Case of Alaybey-Izmir, Turkey
}

\section{Kent Sakinlerinin Kent ve Kentsel Dönüşüm Hakkındaki Görüşlerinin Değerlendirilmesi, İzmir-Alaybey Örneği}

\author{
Burcu Gülay Taşçı \\ Department of Architecture, Dokuz Eylül University Faculty of Architecture, İzmir, Turkey
}

\begin{abstract}
The expansion of the cities after the industrial revolution led to new urban dynamics and cities began to develop in a disorganized way according to arising new needs. This uncontrolled development brought the need for urban transformation/renewal in Turkey as well as in other countries. In Turkey, the terms 'urban transformation' has not clearly been understood by the city dwellers due to the increasing unearned income policies and unmonitored projects. This paper aims to draw attention to this problem and analyze the notion of urban transformation from the perspective of the city dwellers with a case study carried out in Alaybey-Izmir. In the case study which was implemented on two distinct groups, namely children and adults, the survey was employed for data collection. The findings reveal that both the children and the adults were able to detect the problems in their neighborhoods that cause transformation. But they understood the "urban transformation" differently from the definition given in the literature. Based on this result, it is suggested that the awareness of residents regarding the urban transformation should be raised. On the other hand, the expectations from the transformation project differ between children and adults. This result proves the claim that the studies from the perspective of adults cannot represent children. As is seen in the case study, children should be analyzed as a distinct subgroup in studies concerning the urban transformation.
\end{abstract}

Keywords: Adult; children; İzmir-Alaybey; residents' view; urban transformation.

\section{ÖZ}

Endüstri devrimi sonrası kentlerin hızla büyümesi, yeni kentsel dinamikleri doğurmuş ve ortaya çıkan yeni ihtiyaçlar doğrultusunda kentler düzensiz bir şekilde gelişmeye başlamıştır. Bu kontrolsüz gelişme dünyada pek çok ülkede olduğu gibi Türkiye'de de dönüşüm ihtiyacını beraberinde getirmiştir. Türkiye'de kentsel dönüşüm kavramı, maalesef artan rant politikaları ve kontrolsüz yapılan dönüşüm projeleri nedeni ile kentli tarafından yeterince anlaşılamamaktadır. Bu çalışma kentsel dönüşüm konusundaki bu algı karmaşasına dikkat çekmekte ve dönüşüm kavramını Izmir Alaybey örneği ile kent sakinlerinin gözünden incelemeyi hedeflemektedir. Yapılan alan çalışmasında bölgede yaşayan çocuk ve yetişkin iki farklı kullanıcı grup ile çalışıımış, çalışmada veri toplama aracı olarak kısa anket sorularından faydalanıımıştır. Çalışmanın bulguları değerlendirildiğinde, çocuk ve yetişkinlerin, yaşadıkları kentteki problemlere yönelik tespitlerinin benzer olduğu, ancak kentsel dönüşüm kavramının tüm katılımcılar tarafından literatürdeki tanımdan farklı algılandığı tespit edilmiştir. Bu bulguya dayanarak, dönüşüm süreçlerinde kentli kullanıcıların kentsel dönüşüm ile ilgili bilinçlendirilmesi gerektiği söylenebilir. Öte yandan kentsel dönüşüm projesinden beklenenler sorgulandığında, çocuk ve yetişkinler arasında farklılık çıkması, çocuk katılımı almadan, büyüklerin gözü ile yapılan çalışmaların çocukları tam olarak temsil etmediğini göstermiştir. Bu çalışma ile kentsel dönüşümle ilgili yapılacak çalışmalarda çocukların ayrı bir alt grup olarak incelenmesi gerektiği ispatlanmıştır. Anahtar sözcükler: Yetişkin; çocuk; İzmir-Alaybey; kentli görüşleri; kentsel dönüşüm.
Received: 08.01.2016 Accepted: 07.01.2017

Available Online Date: 10.01.2017

Correspondence: Burcu Gülay Taşçı. e-mail: burcugulay@gmail.com
TMMOB

Şehir Plancıları Odası 


\section{Introduction}

Urban transformation is a comprehensive event that is aimed to improve the urban areas that are problematic in the aspects of economy, social - spatial and environmental (Turok, 2005). As an alternative definition, urban transformation may be defined as organizing the properties that are built irregularly, got old, vulnerable to natural disasters and urban risks with insufficient infrastructure and unqualified and densely built structures based on the new master plan data (Ülger, 2010). Keleş defines urban transformation as an informed, systematic and planned event for a whole city or it's certain settlements (Keleş, 2003). In both application and literature, the subject of urban transformation is defined with different concepts like urban renewal, urban regeneration etc. These concepts should be separated from urban transformation in certain aspects. To summarize; the concept of urban renewal, introduced in 1981 by the European Council with a campaign means "to reorganize and apply in order to improve the current cities and centers and to renovate to meet the current requirements" (Hasol, 1998). For Keleş, urban renewal is initiated in order to: i) to clear out the poor areas, ii) to remove the economic barriers between the city centers and their sprawling settlements, iii) to increase the financial resources of the local city governments" (Keleş, 2004). In other words renewal is not only initiated to clear out the poor sections; the applications may include revitalization, preservation and redevelopment and aim to provide a better living standards to the people (Aaen, 1999). However it is seen that with the emerging consciousness to preserve, the concept of urban renewal is being left behind and the term "urban renaissance" is being used. "Urban renaissance" is also defined as providing new legal support for improving the living conditions in cities, to define the current and future role of cities and to improve the urban life in general and to develop relevant administration and technical methods regarding urban related issues (Özden, 2008).

In literature, another term used incorrectly instead of urban transformation is "urban regeneration". Regeneration practices are defined as "during generation of new texture, improving the areas that can be reclaimed and adding to the new texture". Due to its definition, from time to time the urban regeneration practices may be confused with urban transformation (see: Demirkıran, 2008). On the other side, one can say that, based on certain resources, renewal and regeneration practices on district scale should be defined as a tool for transformation (Bailey, 2004).

The main reason for different definitions to emerge is the varying practices of urban transformation studies in different countries (Kocabaş, 2006; Gibson and Langstaff, 198I). To summarize the rise and establishment of the term urban transformation; USA was the first to introduce the term urban transformation; however it is most commonly improved in Western Europe. The process that is initiated after World War II aimed to remedy the destructive trail of the war up to the end of 1970's and meet the housing requirements due to increased population; for this reason, during 1950 to 1970 the focus was on improving the physical housing stock, especially in Great Britain. After 1970, Great Britain and USA went into a transformation process by closing down the industrial areas in city centers and moving them out of the city (Hall, 1997).

In 1980's, by adopting the policies of urban transformation driven mainly by the private sector in USA throughout the world such as Great Britain, the partnership of local governments and the private sector became a rising trend. In this context, major projects oriented towards real estate on the lands that used to host the industrial sector were initiated, however instead of remedying the local issues; these practices served the global policies. Throughout the 1990's, the emerging term was designing high density city areas formed of social and economical residences (urban renaissance). However this term is being criticized from time to time with the claim that it provokes social isolation (Lees, 2003). For this reason, major steps were taken in order to remove the negative aspects of the real estate oriented transformation policies and the idea of having the local residences have a say in the urban transformation process was brought up (Özdemir, 2010).

In recent times, the new focus of the $21^{\text {st }}$ century in Europe may be the issue of "sustainable neighborhood transformation". Forming sustainable communities in urban transformation is in focus now and the subject of urban transformation is being viewed as a mechanism to realize the decisions and the goals on both the national and city scale.

\section{I.I Urban transformation in Turkey}

Urban transformation issue is first surfaced in Turkey due to increased growth of slum settlements on the outer rims of the city. The studies initiated between 1950-1980 was enhanced and moved to the outer city sections. As a result of these studies, the risky areas were renewed, reinvigorated and the historical sections were gentrified and preserved (Ataöv and Osmay, 2007). Following this period, construction of tall apartments in major cities in Turkey with Istanbul taking the lead (Mukul and Sarı, 20I5). With this new development, the terms urban transformation, renewal, restructuring and revitalizing emerged in Turkey as well.

Another incident where the urban transformation was in the spotlight in Turkey was the 1999 Marmara earthquake disaster where 17.480 people lost their lives. After the Marmara earthquake disaster, it highlights the need for immediate 
renovation of the residence and urban infrastructure that is rendered unusable, starting from Istanbul. (Kocabaş, 2006). Following the awareness campaigns run by Republic of Turkey Prime Ministry Housing Development Administration of Turkey (TOKI) and Metropolitan Municipalities, by engaging the private sector as well, various projects were developed throughout Turkey with a focus on the regions that pose a disaster risk.

During the recent period up to today, similar practices were applied as well and the term of transformation is being recognized as a planning strategy (Ataöv and Osmay, 2007).

The first literature discussions were recorded in 2003, the symposium of urban transformation hosted by the TMMOB chamber of city planners. After 2004, for complying with the European Union standards, the issues of urban transformation and renewal were discussed more frequently in our country (Genç, 2008).

Istanbul is one of the cities that urban transformation processes is most frequent. Tekeli classifies the projects undertaken in Istanbul as "projects that consist buildings with high risk, projects focused on slums, gentrifying the available areas in the city and realized projects and fraud projects that have emerged due to ideological choices of the local authorities (Özdemir, 2010). Türkün highlights the state hegemony regarding the structures built in Istanbul and since the public need is disregarded in these projects, they are focused on profit as a result of the neoliberal urban policies (Türkün, 20II).

Türkün's comment for Istanbul may be extended on many practices throughout Turkey. This is due to the influence of Western Europe and USA on Turkey and with a focus on globalization, consumption and profit focused projects are unfortunately prioritized. In particular, from 2000 when the neoliberal policies were realized, with a transformation approach lacking social aspect, mainly the residential investments were incentivized (Göksu and Bal, 20l0).

Lack of understanding the foreign practices, not taking lessons from these practices and focusing on profit instead of forming an urban policy are the reasons for not properly grasping the issue the urban transformation in Turkey. When the practices in question are reviewed in Turkey, at least 9 different practices may be highlighted (Özden, 2008). The legal backgrounds of these applications also vary: municipality law no 5393, legislation regarding the renewal of historical and immovable assets no 5366, metropolitan municipality law no 5216 , collective housing law no 5162, coastal law no 3621 are some of the laws that are formed with exclusive law making practices. Furthermore, with the natural disasters and risky structures being under the spotlight, "Law regarding the transformation of the areas under the risk of natural disaster no 6306" came in effect in 2012. In the recent period, the practices in Turkey mainly focus on remedying the collapsing risk in an event of an earthquake. The practices mainly focus on certain provinces. The case of Izmir "Alaybey", being reviewed in this article is one of the mentioned practices.

When the criticism related to the urban transformation practices in Turkey are reviewed more, the main issue stands out as the "the expectation of maximum profit focusing on real estate, the lack of an inclusive process, disregarding the needs and requests of the local populace" (Özdemir, 20I0).

Similar issues can be seen in Izmir as well. As seen throughout Turkey, the urban transformation projects in Izmir suffer from only being focused on real estate and maximum profit, lacking social aspects and not running an inclusive process. Keeping the local populace isolated from the transformation process leads to the process to be grasped partially by the populace and with independent, different projects, the cities are being isolated from their respective users. As a result, people who live in transformation areas perceive "urban transformation" in different ways.

For this reason, the following sections of the study focused on the importance of the works towards collecting the opinions of the local populace regarding the urban transformation processes and the ambiguity about transformation's analyzed in Alaybey-İzmir, by using questions with regard to public understanding of urban transformation and expectations from an urban transformation project. The main purpose of this study is to understand the residents' views on their neighborhoods in the context of urban transformation and to find out whether the views of residents differ depending on being children or adult.

\section{Theory and Methodology}

\section{I. Caring residents' views in urban transformation processes}

City is a social, cultural and physical phenomenon that affects human life. It is known that human beings are continuously in interaction with the urban environment and positive and negative results of this interaction are still argued today (see; Wells at al., 2010; Macgregor, 2010). Understanding the significance of the relationship between human and the urban environment, has revealed the necessity of user-centered design of cities. This necessity has become a current issue due to increase of urban transformation applications lately and many studies towards receiving opinion from citizens are performed within the urban transformation processes in the recent period (Speak, 2000; Lawless, 2010; Lundy and McEvoy, 
20I I; Bineth, 20I4; Chatterjee, 20I5; O'Connell et al., 20I5). Common purpose of these studies is to integrate people into the process of urban transformation. Apart from this general purpose, within these studies which has been an advocate of approaching urban transformation processes with the community, numerous other reasons can be mentioned as well.

Integrating the city residents to the urban transformation is specified within the "context of right to participate" (Lundy and McEvoy, 20II; Akkoyunlu Ertan et al., 20l3), it is mentioned from time to time to "increase the awareness of being a city resident and environment" (Speak, 2000) and "to ensure user satisfaction and increase ownership of the city landscape" (Severcan, 2012) or "cultural sustainability" (Maginn, 2007) and "social life" as different priorities. In fact, all these reasons imply that approaching the urban transformation processes together with the community is necessary and beneficial, and tell that cities should be built in a way that makes them livable for everyone (Jacobs and Dutton, 2000; Özden, 2008; Görgülü, 2009; Mukul and Sarı, 20I5).

When we look at Turkey, it is observed that most cities are not transformed within this approach. The projects initialized under the name "participation", as stated in the study by Arnstein in 1969, are not inclusive in reality, the actual work is done in order to convince the populace and consist manipulation and therapy (Arnstein, 1969). So one can be said that, for transformation projects the city residents' opinions are often ignored and the urban transformation projects are executed based on the personal opinions of the directors and the experts.

Another issue is that children and the youth are disregarded during these processes. Not only in Turkey, but also in many other countries, children and youth are still in a disregarded category in transformation processes (O'Connell et al., 20I5). Urban landscapes built this way without inclusive policies is estranging the city residents and increasingly turn into environments that do not serve the populace and in turn the populace do not hold ownership for the environment in general.

Especially in disadvantageous areas, this issue becomes more apparent and people living in these spaces think that they have no influence on decisions taken regarding their immediate environment (Smith, 20I I).

However, the citizens have the right to speak on decisions taken regarding the city which they live in. This right is given to everyone without making age discrimination and as a matter of fact, is entitled to children in Convention on the Rights of the Children (UN Convention on the Rights of the Child, 1989). In certain studies performed recently, it is emphasized that views of children are as valuable as adults' views (Speak, 2000). In many countries such as Denmark, Germany, Unit- ed Kingdom and Ireland, the argument that beginning with children, the whole community must participate in decisions taken about the environment they live in, is acknowledged and user-centered urban designs are carried out. Thinking and applying with public is predicated upon urban transformation applications as well, therefore new approaches such as "integrated urban transformation", "participatory urban transformation”, "child-friendly urban transformation" are developed.

Based on the recent studies, a study involving gathering opinions is included here. Making use of opinions of children and youth in a study performed for slum areas in India (Chatterjee, 20I5), determination of urban transformation areas together with the community and investigation of spaces to be transformed with participation of community in Copenhagen (Technical and Environmental Administration Urban Design Department, 2012), cooperation with children for the transformation of mass housing area in the study performed in Ireland (O'Connell et al., 20I5) and such studies based on receiving opinions have been the source of inspiration for this article. In accordance with studies taken as examples in this article, a space that is considered for transformation in İzmir, Turkey, is being reviewed with a user-centered approach. Before moving on to this assessment, the review conducted by the researcher is included here in order to provide information regarding the area of study.

\subsection{Properties of the sample transformation area: Alaybey-Izmir}

İzmir is one of the cities in Turkey in which transformation projects have been carried out due to the risks of disasters. Bordered by the Aegean Sea, it is a gulf city in the west of Anatolia (see Figure I). İzmir is the third densely-populated city in Turkey with a population number 4.II3.072 (TUIK, 20I5).

The culture of the city that has roots in ancient era and its layered structure have brought the preservation and transformation issues into question. Following the Marmara Earthquake, renewal and transformation of improperly urbanized sections of İzmir is important.

Based on the declarations made by İzmir Metropolitan Municipality, an area up to $437 \mathrm{I}$ hectares to be renewed focusing on the improper urbanized sections. In this respect, new urban renewal areas are constantly being declared, in addition to the fact that the renewal of inactive and dilapidated old constructions has been particularly prioritized. District municipalities also contribute to studies within this framework.

Such transformation studies are predominantly carried out in a building scale by means of individual efforts. They are also 


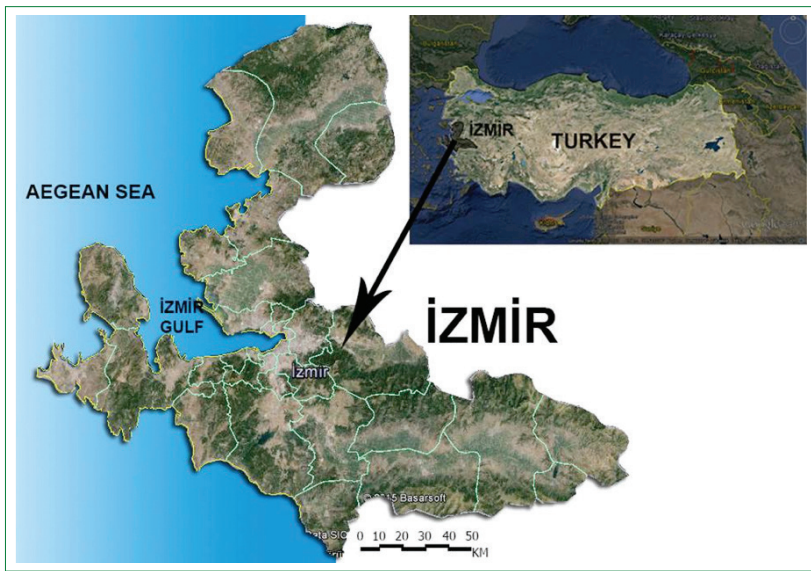

Figure I. Turkey, İzmir.

implemented on the basis of districts in a holistic way as is the case in the Municipality of Karşıyaka District.

Karşıyaka is a district in İzmir with a population of 325.717 and it is situated in an area of $84 \mathrm{~km}$ in the northern coasts of İzmir gulf (see Figure 2). This district was opened to settlement with the coming of İzmir-Menemen railway into service in 1865, and it has developed rapidly since the sea transportation to other districts was launched in 1874 .

Based on the information gathered from Karşıyaka Municipality Directorate of Planning and Projects, the area which is considered to be renewed in near future in Karşıyaka district is approximately $93.000 \mathrm{~m}^{2}$. Within this area, there are six neighborhoods: Alaybey, Tersane, Tuna, Bahriye Üçok, Donanmacı and Bahariye.

For the area consisting of these 6 neighborhoohds, there are no finished works. When reached to Karşıyaka municipality regarding the planned practices for Karşıyaka, the information below is obtained:

The first neighborhood to be planned for works is Alaybey. The initial goal of the municipality is to include the private sector to the urban renewal process and establish the region a center of attraction for investors. Karşıyaka municipality first prepared an "urban renewal" project for the borough and presented the project to Metropolitan Municipality and announced it to inform the residents.

However, the municipality cancelled the project due to receiving a rejection from the Metropolitan Municipality due to certain reasons (for instance lack of site investigation, ground studies etc.) and initialized another project and referred to Ministry of Environment and Urbanization based on "urban transformation" law no 6306 (law, regarding the transformation of areas under natural disaster risk). The goal of the proj-

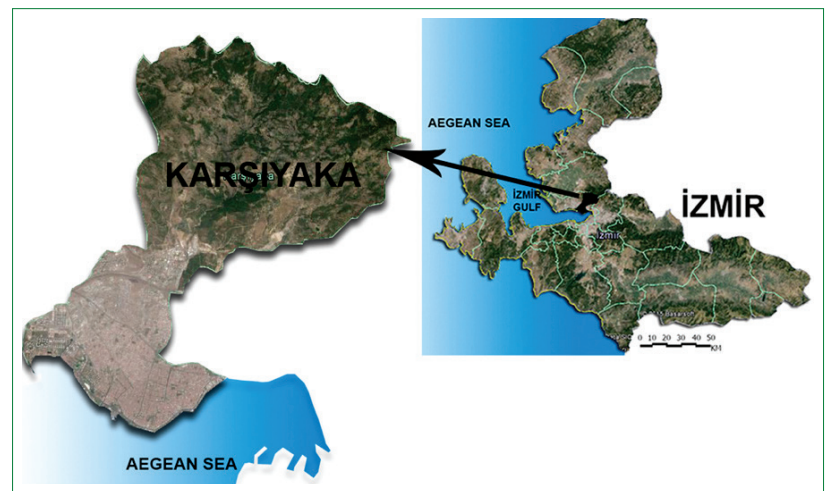

Figure 2. İzmir, Karşıyaka.

ect is specified as "To declare Alaybey as a region of urban transformation due to risky structures within the borough and immediately improve the borough". Following the local elections, due to the government changing hands, the process is once more delayed; however the new government also assumed the prior plan. Based on this plan, the residents that have the financial strength initiate their own renewal works on structures.

As it is understood, urban renewal and transformation are unfortunately assumed as interchangeable practices that include different legal processes. Due to this conflict in terms, the residents are not informed properly. For this reason, the shared study initially focused on this section highlighted in Karşıyaka regarding urban transformation term and initially focused on properly promoting the region.

According to the information obtained from the analysis of the documents, this area has been one of the oldest settlements areas of İzmir. When the former appearance of the area is compared to its recent appearance, the type of building is worth-noticing, and the traces of the increasing population along with the changing public works can be read from these changes (see Figure 3). Within the borough that has a sea shore, the inner sections are cut off from the shore due to tall and aligned structuring.

The planned transformation area is bordered by İzmir gulf in east and south. The key access to the area bordered by the sea on one side is from the coastline. Bahriye Üçok and Girne Boulevards are used as a second option. The railway constituting the other border of the area was moved to underground and it has lost its bordering property after the remaining area has been transformed into a green field (see Figure 4).

Within the borders of the area, the streets are commonly shared by both the vehicles and the pedestrians. Only the streets in the market place have been pedestrianized. 


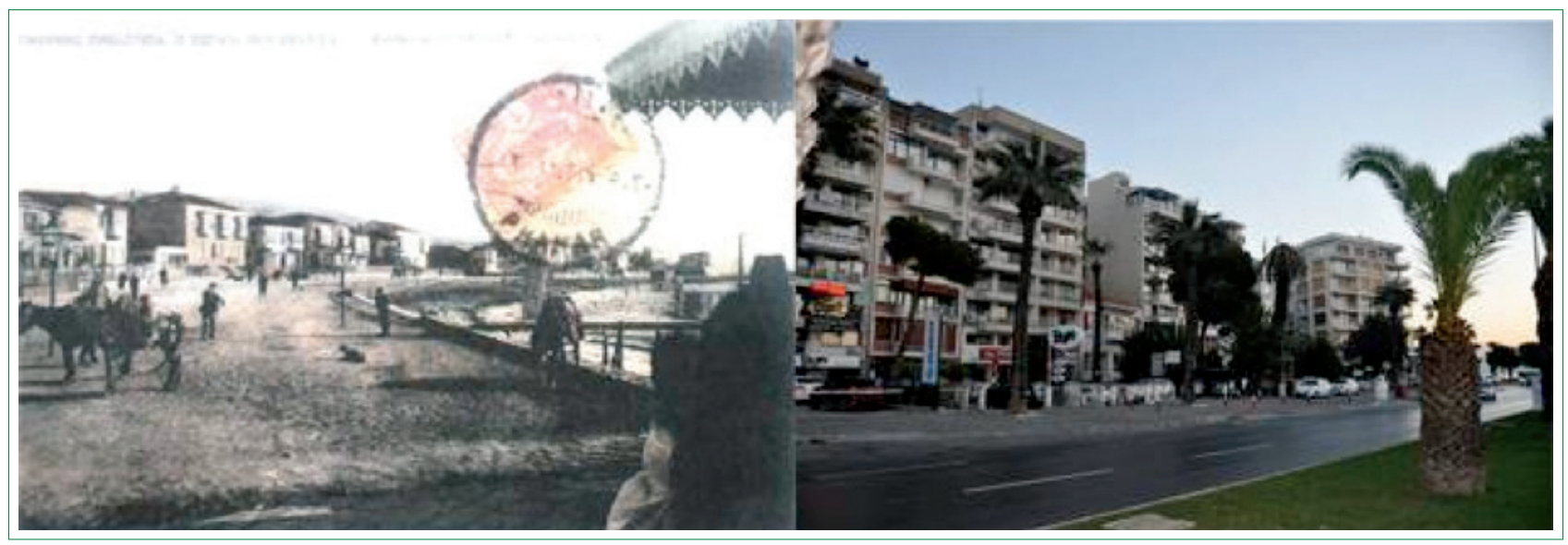

Figure 3. Old and recent views from the coast line.

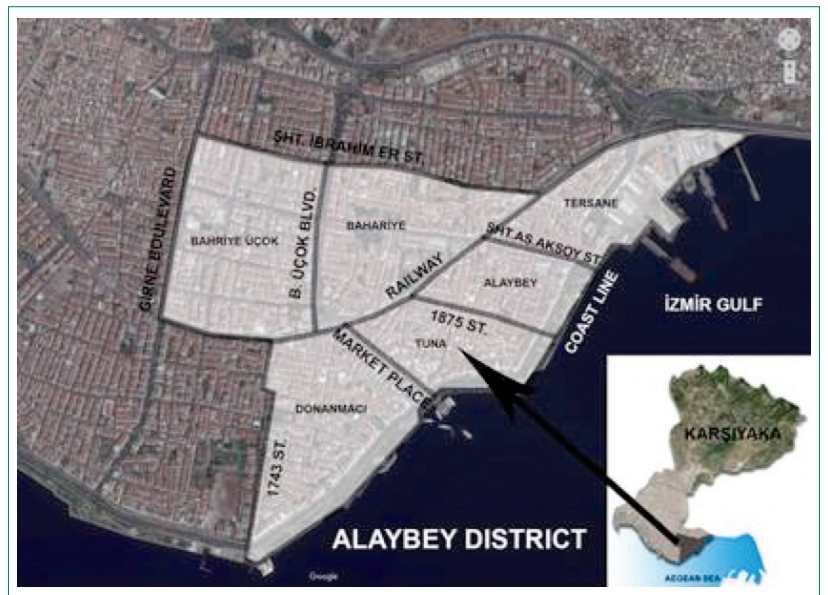

Figure 4. Planned urban transformation area in Karşıyaka.

On all other secondary roads, high vehicles have priority (see Figure 5).

Since there is no underground parking lot or no building that serves as a parking space, all side streets have become areas on which vehicles are parked as one or two sided (see Figure 6). It has been observed that the streets lost their public function due to the transformation of streets into parking lots. It has also been observed that no legal penalty is implemented on such random parking on streets. Ideal public places are defined as places easily passable into and through (Francis, 2003), whereas pedestrians cannot walk securely in the streets even not on the sidewalks in these areas.

The narrowness of the streets influences the pedestrians in a negative way. It has been ascertained that the streets in this area are commonly between 6-7 meters, which should be averagely 13-14 meters with its sidewalks and grass verges in a residential area (Emms, 20II). It has been found out that the road to the school in the area has not still been pedestrianized.

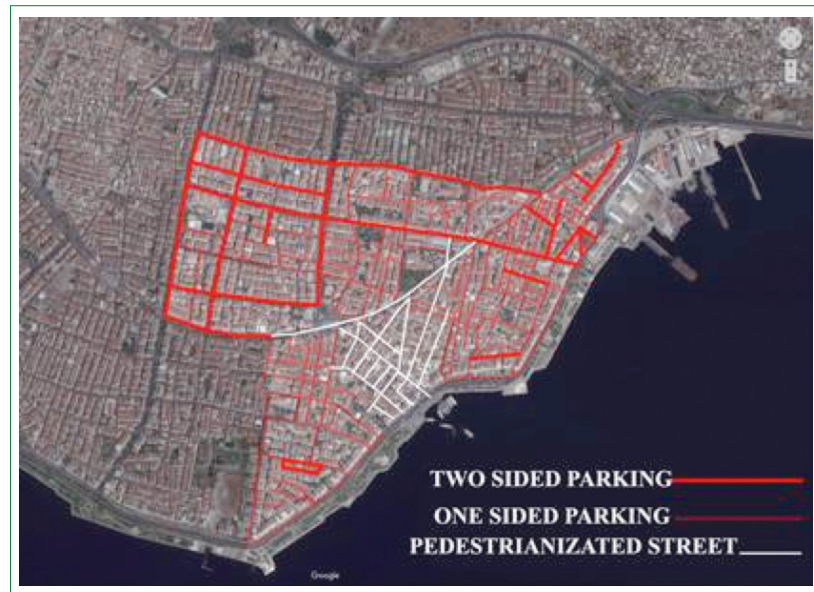

Figure 5. Priority of streets in the area.

For this reason the students face dangers on streets and even on the sidewalks. Based on the study by Bruce Appleyard, it may be arguably said that the streets in the area affect negatively the perception of the city by children (Appleyard, 2003).

The amount of green space open to public is reviewed, it is seen that on a $2.000 .000 \mathrm{~m}^{2}$ area, $40.000 \mathrm{~m}^{2}$ area is reserved for green space, in other words, only $2 \%$ of the total area is reserved for green space. Almost all of this green area is constituted by the coastal line (see Figure 7). Therefore, one can conclude that this nonhomogeneous amount of green area is insufficient since in the literature, it is stated that the active green space per capita should not be lower than $10 \mathrm{~m}^{2}$ according to Turkish Republic the Ministry of Public Works and Settlement (MPWS) standards (Önder, et al., 20I I).

Almost a few play spaces have been observed within the whole research area (see Figure 7). Based on literature the streets are used as playgrounds where playgrounds do not exist (Gülay Taşçı, 2010). However when the space composi- 

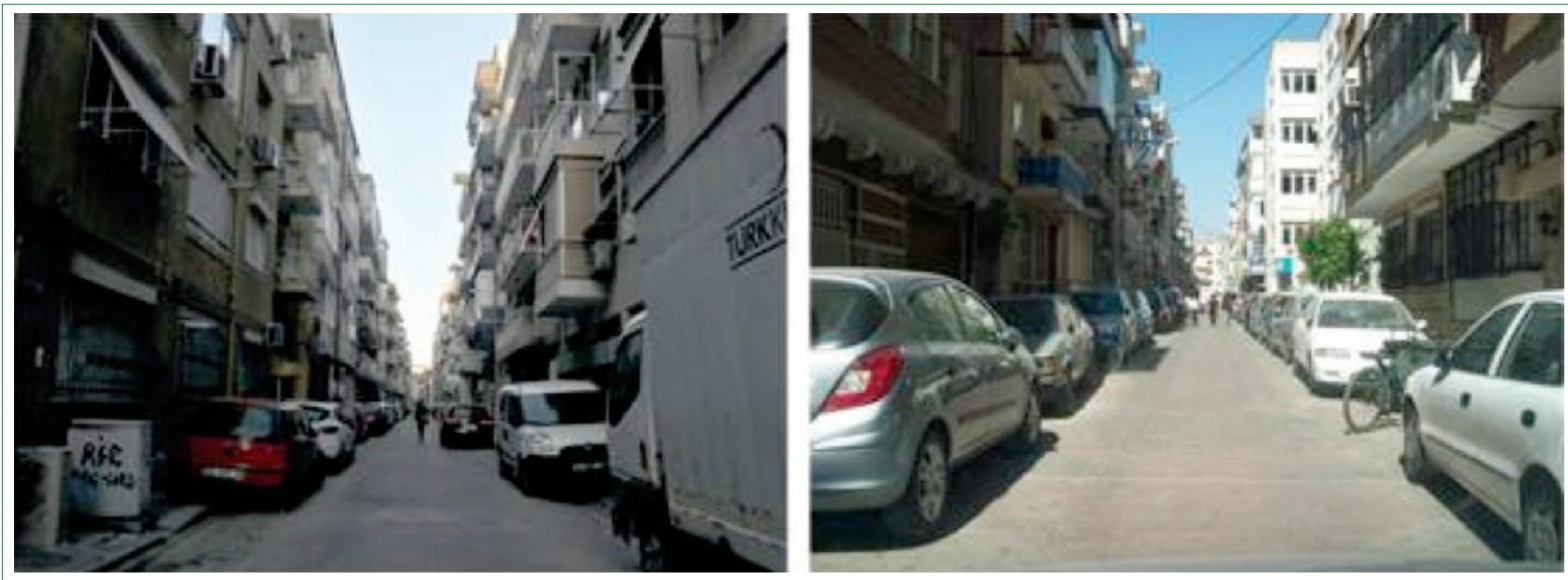

Figure 6. General view of streets, Alaybey.

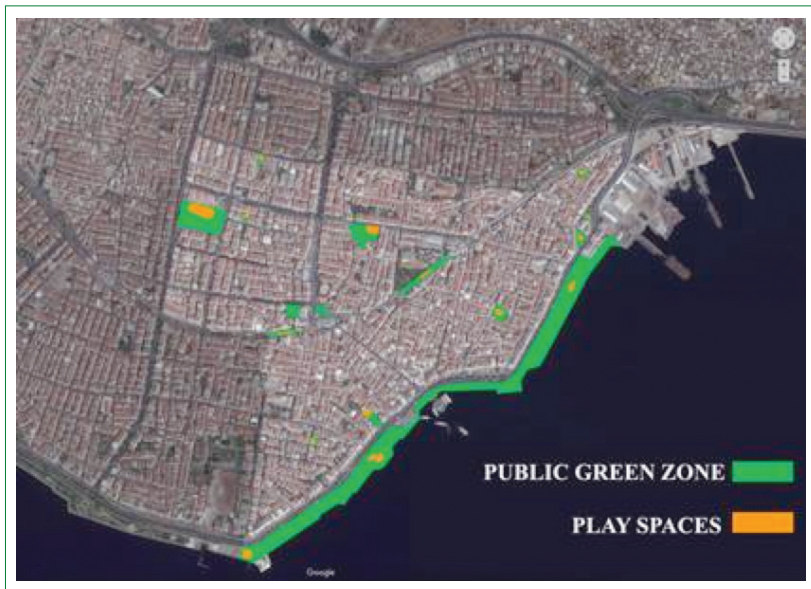

Figure 7. Public green zones and play spaces in the area.

tion is reviewed in Alaybey, the streets lost its function as a playground due to dense traffic.

When the buildings are analyzed in the area, it has been observed that the buildings are mostly designed for housing and commercial functions. No other function has been observed in the area besides these. The number of the areas for sports, education and cultural activities for young and old people is very scarce. There is neither enough space for social functions nor indoor space (see Figure 8).

It has been observed that the building typology is mostly apartments (see Figure 9). In 4-8 floored apartments normal floors are used for dwelling while the basement floor is mostly used for commercial purposes. The whole area has a structure that can be used for 24 hours since the commercial activities in the area have been generally developed by the retail sectors which will meet the needs of the housing fabric.

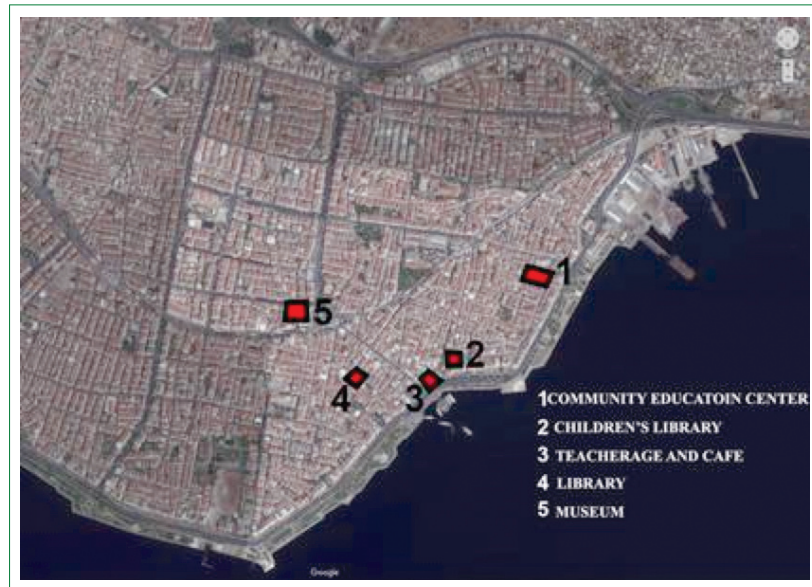

Figure 8. Indoor social facilities in the area.

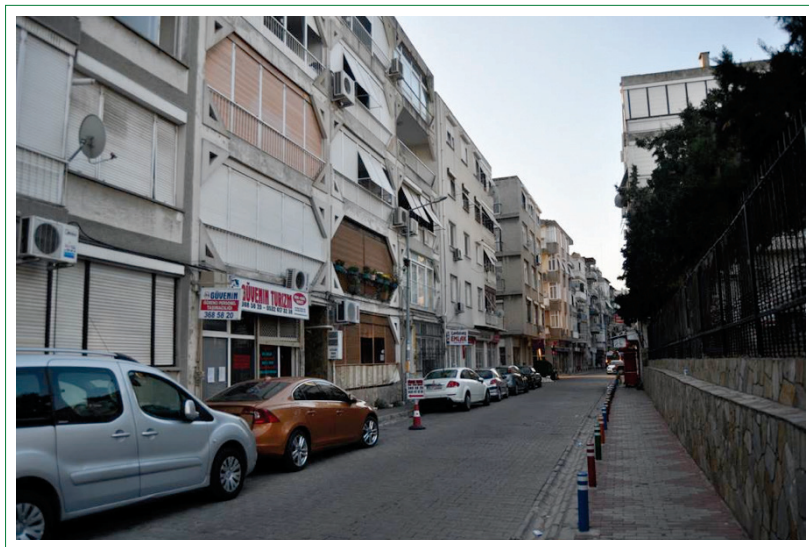

Figure 9. General building typology.

The quality of the structures was analyzed in the last phase of the preliminary research carried out on the area. Based on the information taken from the municipality, it has been found out that most of the buildings are 30-40 years old and 


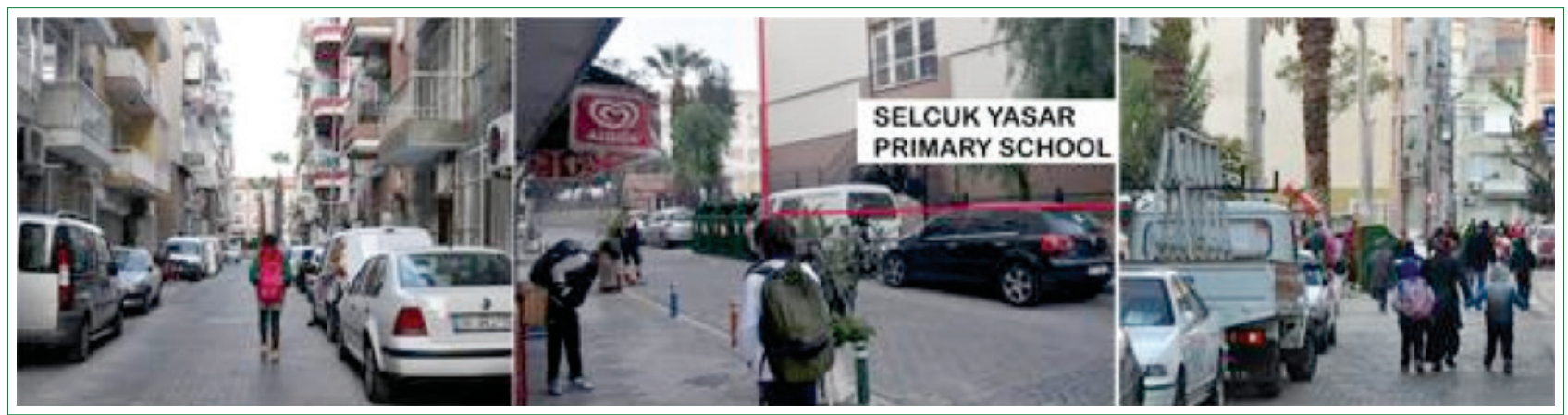

Figure 10. Children commute to school in Alaybey.

that they were constructed with reinforced concrete. Having already expired their date of uses, these constructions are faced with the risk of being demolished by an earthquake.

When the borough headmen are consulted, they specified that only small portions of the populace try to demolish and reconstruct their buildings, the majority cannot initiate such projects due to financial difficulties.

These findings based on observations, municipality documents and interviews with the authorities bear out the claim that the density of housing is much more than expected and that the area should be transformation due to many reasons. The most prominent reason is the earthquake; therefore the Municipality of Karşıyaka wants to declare this area as a transformation area, with law no 6306 regarding the transformation of areas under natural disaster risk since it bears a risk of disaster. From the interviews with the Plan and Project Management of Municipality of Karşıyaka on the related topic, it has been learned that the aim is "to change the master plan and to draw investors to the region and increase the value of the region". Then the issue is: What does urban transformation process mean for the public, that the municipality initiated to handle the issue of earthquake?"

The rest of the study is seeking an answer to this question, and it presents a different perspective to the process of transformation by means of taking the views of residents within the scope of a case study.

\subsection{Method of the study}

Study used the screening model for researching user views. In a universe composed of many elements, an extracted sample out of the universe can be studied to reach to a conclusion about the universe in the screening model. There are subgroups which can be compared within this sample in the relational screening model (Selltiz et al., 1963).

In this study, the children and the adults residing in the trans- formation area were determined as the universe in order to specify the views of the participants, and the $4^{\text {th }}$ and $5^{\text {th }}$ grade (age I0-II) students of a central school in Alaybey (Selçuk Yaşar Primary School) and their parents were chosen as the sample group. The children and their parents were analyzed comparatively within this sample.

The study were first launched with 84 available people who had first accepted to take part in the study, but it was completed with 78 people (39 students and 39 parents) owing to the fact that some parents rejected filling in a questionnaire during the research process. The study was carried out after the necessary permissions were granted by the İzmir Provincial Directorate of National Education and the management of Selçuk Yaşar Primary School.

To determine the students that will be included in the study are based on the permission obtained from the administration and with suitable schedule, the numerical equivalence between boys and girls are not observed. For this reason an evaluation based on gender is not conducted.

The determining factors were the age group and the school in choosing the child participants. Studying in a school was a preferred reason due to the fact that it is easier to find students of the same age range together at the same time.

Following Appleyard's study, the location of the school was taken as the basic criterion in determining the school. In Appleyard's study, it is stated that the awareness of students walking to school is higher than students going to school by means of a vehicle (Appleyard, 1981). And it is thought that the environmental awareness is necessary for children to make interpretation about urban transformation. Therefore, a central school of the residential area was chosen depending on that criterion. The question as to whether the children commute to school on foot was borne out by means of observations (see Figure 10) and interviews with their teachers.

The reason as to why the children whose ages ranged be- 
tween 10 and II were used as participants was that they have already passed through the abstract operational stage and they have the ability to disclose their opinion about the abstract term "urban transformation".

In choosing the other group of participants, namely adults, the correlation between the children and the adults was taken into consideration. Seeing that conversations and interactions within the family may affect the perception of children based on the study by O'Connell, et al. (20I5), adults thus was not selected at random.

In order to eliminate the differences between the children due to living in different homes, children and adults from the same house is included in the study. In other words, the perceived urban transformation concept may be inherited from the parents before the study is taken into consideration.

\subsection{Data collection tools}

The study employed the surveys as the written documents in addition to the researcher's own observations. At the beginning of the study, as an introduction to "urban transformation" subject, the questions "what are the urban problems of Alaybey?" and "what can be the solution suggestions?" were asked to children and parents separately. Then the following questions: "What is urban transformation? What do you understand from the term "urban transformation?", "-What are your expectations from an urban transformation project?" were asked.

It was predicted that defining evaluation parameters beforehand could be misleading; therefore, open-ended questions that participants might freely state their views were used as a tool.

\subsection{Assumptions}

The participants are assumed to have answered the survey questions in a sincere and truthful way. It is assumed that the data gathering tool will allow all opinions to be received.

\subsection{Limitations of the study}

There are some limitations in the study regarding the research topic and the sample. The research topic has been limited to "problems of Alaybey, definition of urban transformation and expectations from the urban transformation project". The sample has also been bordered by the children who are I0-II years old, and their parents.

\subsection{Analysis of the data}

Since the child and adult participants were dependent samples in the research, Mc Nemar Test, which is a two-sample test in dependent groups, was employed in the main statistical analysis of the data assembled in a qualitative way. The answers to the open-ended questions were first encoded by the researcher, and then these answers were entered in the Statistical Package for Social Sciences (SPSS). After that, these data were analyzed by means of Mc Nemar Test.

\section{Results and Discussion}

\section{I. The problems and solutions}

The findings of the study are presented in an order according to the given answers. The answers of the participants in handwriting were grouped under similar titles by the researcher. The findings of the first and second questions as to the urban problems and solution suggestions of Alaybey have been summarized below (Table I):

Not all participants mentioned these problems in the same proportion (see Figure II). The percentages concerning the mentioning of the problems according to the adults and children are as follows:

As seen in Figure II, the most mentioned problem is the low quality of streets. Most of the participants marked the low quality of streets as a problem since they are used as parking lots, although they did not mention the low quality of the building with the same frequency.

As for the problem of parking, it can be said that the number of the adult participants stating it as a problem is higher than the child participants. However, the situation is reverse in terms of traffic problem. Here, one can conclude that the adult participants use the area with their vehicles while the child participants use the area as pedestrians. Children who commute to school on foot cannot use the street as a playground. As for the problem of the absence of playgrounds, it can be stated that the tendency of the child participants to see it as a problem is higher than the adult participants.

When the answers with respect to the absence of green lands are considered, it can be seen that both child and adult participants paid reasonable attention to the green space, which are seen as a socialization space. However, the absence of indoor socialization spaces was not mentioned as much as the absence of green lands.

Thus, it can be concluded that the deficiencies in buildingscale were not marked as a primary problem. The fact that the rates of their stating the risks of being demolished by an earthquake were the lowest rates reveals that the problems in building-scale were ignored. Although earthquake is defined by the municipality as the first motivation towards 
Table I. The problems mentioned by all participants

\begin{tabular}{|c|c|}
\hline Problems detected in Alaybey & Solution suggestions \\
\hline Earthquake and unstable buildings & Earthquake-resistant, stable buildings should be designed. \\
\hline \multirow[t]{2}{*}{ Lack of play space } & The streets should be extended. \\
\hline & Playgrounds should be designed. \\
\hline \multirow[t]{2}{*}{ Low quality of streets } & The streets should be extended. \\
\hline & The streets should be cleaned. \\
\hline \multirow[t]{6}{*}{ Low quality of buildings } & Old buildings should be repaired, renewed. \\
\hline & Old buildings should be demolished and rebuilt. \\
\hline & Single story houses should be built. \\
\hline & Each building should have a garden. \\
\hline & Each building should have its own parking lot. \\
\hline & Houses should be located in special residence area. \\
\hline \multirow[t]{2}{*}{ Parking area } & Multistory car parks should be designed. \\
\hline & Parking prohibition should be imposed. \\
\hline \multirow[t]{2}{*}{ Traffic problem } & Traffic calming should be carried out. Some roads should be closed to vehicle traffic \\
\hline & The number of traffic signs for pedestrians should be increased. \\
\hline Lack of green space & The number of green lands should be increased \\
\hline Lack of social facilities & The number of sports, culture and activity areas should be increased. \\
\hline
\end{tabular}

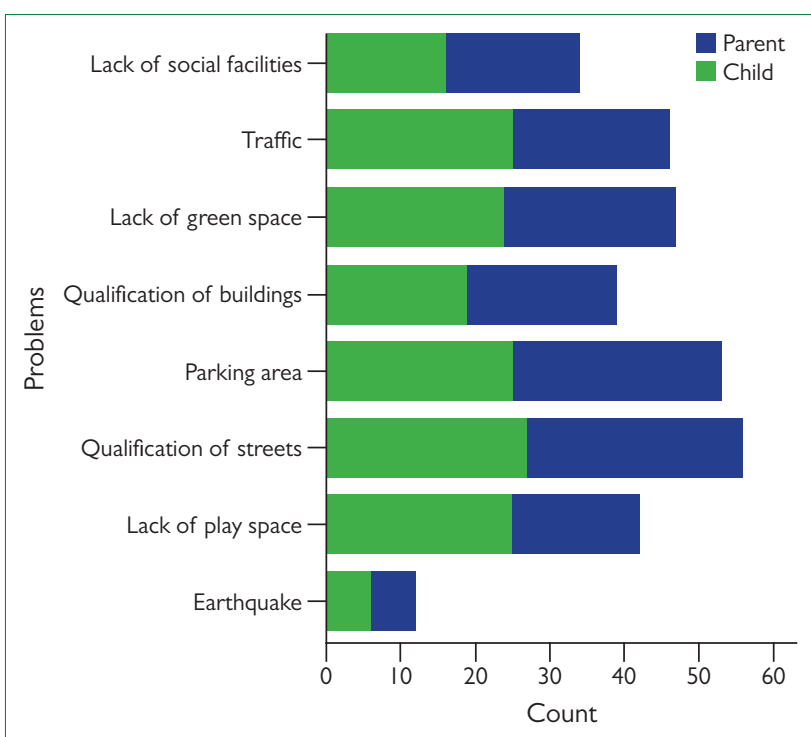

Figure II. The rate of children and adults to vocalize the problems.

the urban transformation, the awareness of both children and adults came out as the lowest rate (see Figure II).

\subsection{Definition of "urban transformation"}

After the pre-research about urban awareness, the second question of survey investigated the differences concerning

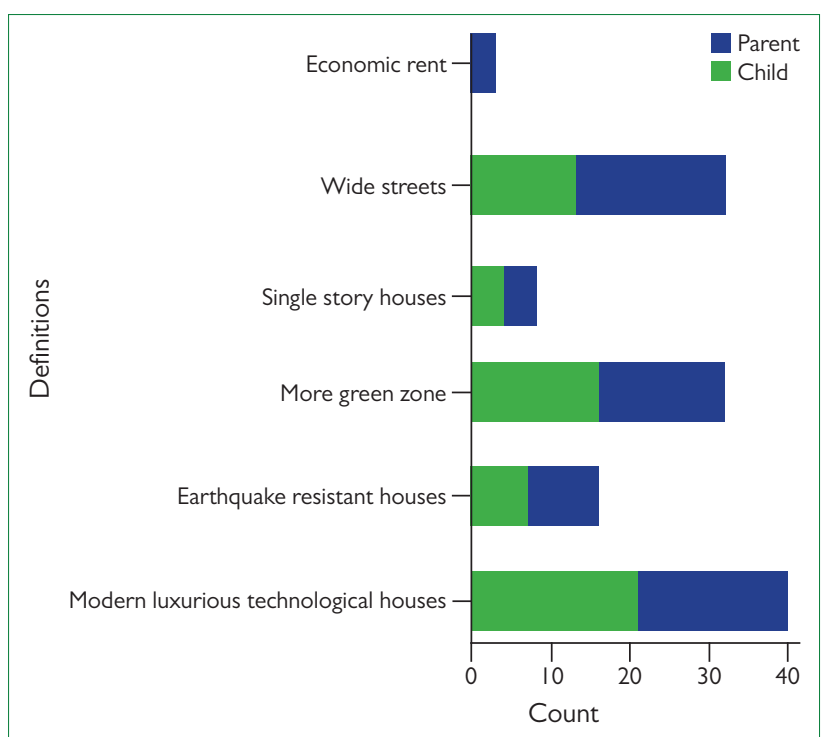

Figure 12. Frequent expressions in the definitions of the child and adult participants.

the "definition of the concept of urban transformation". In this respect, $28.2 \%$ of the child participants and $12.8 \%$ of the adult participants stated that they did not know the answer of the question "Can you define the urban transformation?". The rest of the participants remarked that they knew the answer. However, they defined the term with priorities which differ from the ones provided in literature (see Figure 12). 
The people who claim to "know what urban transformation" commonly answer as "to have homes that are modern, luxurious and sturdy." Furthermore another common feature as an answer is the city to have more green space and have more spacious streets and avenues.

In addition to these definitions, there are some applicants who defined the urban transformation as financial income. $8.8 \%$ of the adults specified that they do not believe in urban transformation and they consider that transformation is merely for " transformation for profits". These limited responses that do not apply to the definition in literature specifies that the urban transformation is not fully understood by the populace and incorrect judgments were cast regarding urban transformation.

\subsection{The expectations from urban transformation project}

The last question of the survey interrogated the participants' expectations from the project in order to evaluate the urban transformation project designed by the Municipality of Karşıyaka. I adult and 3 child participants did not state their expectations from the project. The remaining participants were easily able to express their expectations. Some of the children's' interpretations were as follows:

Pseudonym Blue, II year-old girl: "Urban transformation means that the houses become very beautiful. Our houses will be demolished since they are old. I dream of living in a luxurious home. I wish that our home would be so tall that it could touch the clouds. We have no elevators in our buildings. I wish to have a luxurious elevator in our new home. I dream of a site with a garden and a pool. So, my mom would let me play in the garden."

Pseudonym Flower, 10 year-old girl: "My expectation from the urban transformation is a city in which wide streets and houses with gardens would exist. There would be trees everywhere. There would be a playground just in the middle of the city I am dreaming of. My school and my house would be very close to this park."

Pseudonym Princess, II year-old girl: "l'd like to live in a city in which there would be large parks. To me, there should be parks everywhere. Our home is far from the park. There are too many cars on streets. The city I dream of is composed of gated communities. It would be a safe place. There would be car parks. The children would be flying their kites safely"

Pseudonym Ironman, 10 year-old boy: "I dream of high-rise buildings. I wish to transport from one house to another by means of a mechanism hung on a rope. On ground, bicycles should be used instead of cars. There should be playgrounds in which children could climb with ropes. I dream of many more playgrounds."

Pseudonym Sinan the Architect, 10 year-old boy: "The most significant property of the city in my dream is that it would be neat and large. My greatest expectation is the playgrounds and sports fields. I wish there would be fewer buildings than there are now. I suggest cycling roads for transportation.”

Pseudonym Pink, II year-old girl: "My expectation from the urban transformation project is to reorganize the transportation. I don't find streets secure. The cars ruin the streets. I wish that I could fly from a place to another. Besides, my biggest dream is to have beautiful playgrounds in my city. I wish there would be a pool in the playground. I dream of the scene that the roads would be covered with trees."

When the expectations of the adults regarding the urban transformation project, the issue of traffic is highlighted most frequently. Parents indicate that the streets of Alaybey are problematic, that they cannot even walk on the pavements and they are being used as parking lots by the cars. Furthermore the run down streets, the lack of public spaces are specified are major issues. In urban transformation practices in literature, organizing the traffic volume and improving the streets are also taken into consideration (Kocabaş, 2006). For this reason, one of the major goals of the transformation projects should be the mentioned expectations of the parents.

Another issue specified by the adults is the lack of green space and lack of social reinforcement. In many surveys the question was answered as "we cannot find an open space that we can spend time in or gather with friends. We and our children lack the space to spend time in".

In addition, the answers of the adults consist the renewal of the residences with luxurious and modern counterparts. However they don't give importance to the earthquake risks. When the expressions of the children and adult participants are grouped under similar titles and evaluated together, the distribution is as follows:

As seen in Figure 13, the least mentioned expectation is the earthquake-resistant buildings as shown in the graphic, while the most mentioned expectation is a traffic-free city with green lands and playgrounds. Here, one can conclude that the participants had no idea as to what primary reason would be the driving force for the urban transformation in Alaybey, although Alaybey hosts an information office that informed the local populace that the residences still pose a risk against earthquake. 


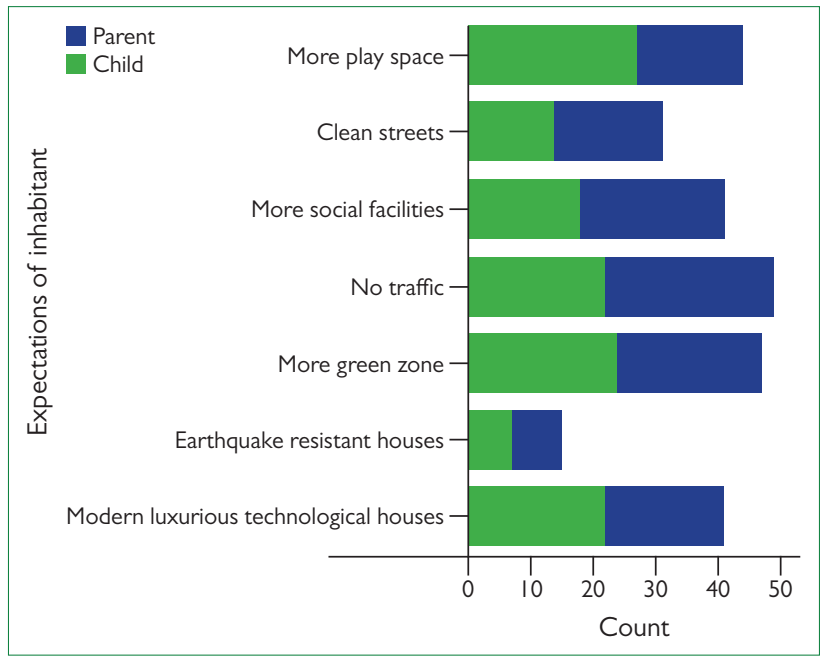

Figure 13. The expectations of the children and adults from the urban transformation project.

Table 2. Statistical results

\begin{tabular}{|c|c|c|}
\hline \multicolumn{3}{|l|}{ Test statistics } \\
\hline & $\mathbf{n}$ & $\begin{array}{c}\text { Mc nemar } \\
\text { test } P\end{array}$ \\
\hline \multicolumn{3}{|l|}{ Mentioned problems } \\
\hline Eartquake & 39 & 1.000 \\
\hline Lack of play space & 39 & 0.096 \\
\hline Street qualification & 39 & 0.754 \\
\hline Parking area & 39 & 0.607 \\
\hline Building qualification & 39 & 1.000 \\
\hline Lack of green space & 39 & 1.000 \\
\hline Traffic children/ & 39 & 0.388 \\
\hline Lack of social facility & 39 & 0.791 \\
\hline \multicolumn{3}{|l|}{ Definitions } \\
\hline Modern, luxurious house & 26 & 0.227 \\
\hline Earthquake resistant house & 26 & 1.000 \\
\hline Green zones & 26 & 1.000 \\
\hline Single-story housing & 26 & 1.000 \\
\hline Wide streets & 26 & 0.508 \\
\hline Economic rent, unearned income & 26 & 0.500 \\
\hline \multicolumn{3}{|l|}{ Expectations } \\
\hline Modern, luxurious house & 35 & 0.454 \\
\hline Earthquake resistant house & 35 & 1.000 \\
\hline Green zones & 35 & 0.815 \\
\hline No traffic & 35 & 0.549 \\
\hline More social facilities & 35 & 0.267 \\
\hline Clean streets & 35 & 0.454 \\
\hline Play space & 35 & 0.022 \\
\hline
\end{tabular}

Is there a statistically significant difference between the children and adults. $P$ values are for a two-tailed test

\subsection{Statistical results}

All these findings stated in a general sense were evaluated depending on whether there is a statistically significant difference between the children and adults.

In terms of the hypotheses shaped according to the questionnaire and Mc Nemar test, the results are as in Table 2. Considering the $P$ value, one can say the difference is not statistically significant between the children and the adults in terms of "mentioning urban problems" and "defining urban transformation" since it is $p>\alpha$ on $\alpha=0.05$ significance level. On the other side, for the last question, when we take the $P$ value into consideration, the fact that the expectations of the children and adults from the urban transformation are the same was refused with a confidence rate $95 \%$ since there is $p=0.022$ on $\alpha=0.05$ significance level and it is $p<\alpha$. We can say that there is a statistically significant difference between the children and their parents in terms of their expectations of "play spaces".

\section{Conclusion and Implications}

This study, which was on the city and urban transformation, was carried out with the participation of users and it revealed the value of the participant views. The participants were able to state all the problems detected in the analysis carried out in the area before applying the survey questions. However, the problem of earthquake was expected to display the highest frequency, yet it turned out to be the least mentioned topic, which indicates that the priorities of the participants are not same with the priorities of the area.

Similar data emerged when defining the urban transformation. The idea of building luxurious houses equipped with technological opportunities stands out rather than the idea of building earthquake-resistant buildings in the area which is prone to a destructive earthquake. This indicates that the notion of urban transformation has not been fully comprehended.

As for the expectations from an urban transformation, variations were observed in the expectations of the participants depending on their ages. It was found that parents do not prioritize building new playgrounds in the scope of expectations from an urban transformation.

On the basis of the results of the study, the following suggestions are made for the future studies:

Firstly, the public should be informed as to what the urban transformation is and why it should be carried out. 
Secondly, the areas to be transformed must be comprehended properly by the city-dwellers. It is suggested that the urban problems should be discussed with contributions of planners, architects, city-dwellers and representatives of local authorities.

And lastly it must be said that, to receive the contributions of the public, a guide that local administrations should comply with regarding the participation ought to be prepared and a participation model needs to be developed for each stage from decision-making to implementation in the process of urban transformation.

This participation model should be flexible as to be able to be localized according to wherever it will be applied to. It should include a participation strategy for each age group, and especially children and the young should be regarded as different groups. It is thought that the first thing to be materialized in this respect should be introduction of urban transformation into school and classes. This may make it possible to eliminate the gap between the local administrations and the children as well as the young.

Note that the urban transformation should be analyzed from the perspectives of the users as well since the aim of an urban transformation is to create a livable city for everyone.

\section{Acknowledgments}

I owe gratitude to the İzmir Provincial Directorate of $\mathrm{Na}$ tional Education, which granted the necessary permissions to carry out the study, to the Plan and Project Management of Municipality of Karşıyaka, which contributed to the study, and to the students and their parents of Alaybey Selçuk Yaşar Primary School, who helped enrich the study with their valuable comments and views. 


\section{REFERENCES}

Aaen S. (1999). National Strategies For Urban Renewal and Housing Rehabilitation in Norway. Andersen H. S. and Leather P. (ed.s) Housing Renewal in Europe, Great Britain: The Policy Press.

Appleyard, B. (2003). Planning safe routes to school. Planning Magazine. Available at: http://www.saferoutestoschools.org/Pressroom/Planning SRTS.shtml. Last accessed: March, 29, 2014.

Appleyard, D. (1981). Livable streets. Berkeley and Los Angales: University of California Press.

Arnstein, S.R. (1969). A ladder of citizen participation. Journal of American Institute of Planners, 35, 216-224.

Ataöv, A and Osmay, S. (2007). A methodological approach to urban regeneration in Turkey. Metu Jfa, 24 (2) 57-82.

Bailey, N. (2004). Konuta yönelik dönüşüm. Glasgow Deneyimi. Uluslararası Kentsel Dönüşüm Uygulamaları Sempozyumu: Küçükçekmece atölye çalışması, 27-30 kasım 2004 istanbul.

Bineth, G. (2014). Urban planning with and for children as a lever for collaborative urban renewal, Available at: http://www.democratic.co.il/media/ capsules_file/ urban_planning_IDE.pdf. Last accessed: June, 17, 2015.

Chatterjee, S. (2015). Making children matter in slum transformations: Lessons from India's National urban renewal mission. Journal of Urban Design 20 (4), 479-506.

Demirkıran, S. (2008). Türkiyéde kentsel dönüşüm uygulamalarinda yerel yönetimlerin rolü: Bursa Büyükșehir Belediyesi örneği. Master Thesis, Edirne: Trakya University Institute of Social Sciences.

Emms, H. (2011). Street design guide. Developer guidance. Newcastle City Council. Available at: https://www.newcastle.gov.uk/wwwfileroot/legacy/regen/plantrans/Street DesignGuideMarch2011.pdf. Last accessed: August, 22, 2014

Fitzpatrick, S., Hastings, A., \& Kintrea, K. (1995). Including young people in urban regeneration: A lot to learn? Bristol, UK: The Polity Press.

Francis, M. (2003). Urban open space: designing for user needs. Washington, DC: Island Press.

Genç, N. (2008). Türkiyéde kentsel dönüşüm: Mevzuat ve uygulamaların genel görünümü. Yönetim ve Ekonomi 15 (1), 115-130.

Gibson, M., and Langstaff, M. (1981). An introduction to urban renewal. London, UK: Hutchinson Publishers.

Göksu, E. and Bal, E. (2010).Türkyéde neoliberal mekansal gelișim staratejisi olarak kentsel dönüșüm projeleri, D. Özdemir (ed), Kentsel Dönüșümde Politika, Mevzuat, Uygulama. Avrupa Deneyimi, İstanbul Uygulamaları içinde, Ankara: Nobel Yayınları.

Görgülü, Z. (2009). “Kentsel Dönüşüm ve Ülkemiz", TMMOB, İzmir Kent Sempozyumu Bildiriler, 08-10 Ocak: Sayfa: 767-780 İzmir.

Gülay Taşç1, B. (2010). An Evaluation of Street as Children Play space. Master Thesis, İzmir: Dokuz Eylül University the Graduate School of Natural and Applied Sciences.

Hall, P. (1997). The first megacities lecture. Megacities, World Cities and Global Cities, The Hague, Available at: http://www.megacities.nl/ Last accessed: June, 01, 2016.

Hasol, D. (1998). Ansiklopedik Mimarlık Sözlüğü, İstanbul: YEM Yayınları.

Jacobs, B., Dutton, C.(2000): 'Social and community issues' in Roberts, P and Sykes, H (ed.s) Urban regeneration handbook, London: Sage.

Keleş, R. (2003). Urban Regeneration in İstanbul, paper presented at the priority action programme, Regional Activity Centre, May 2003:Split.

Keleş, R. (2004). Kentleşme Politikası. Ankara: İmge Kitabevi Yayınları.

Kocabaş, A. (2006). Kentsel Dönüşüm, İngiltere Deneyimi ve Türkiyédeki Beklentiler, İstanbul: Literatür Yayıncllı.

Lawless, P. (2010). Urban regeneration: Is there a future?, People, Place \& Policy Online 4 (1), 24-28.

Lees, L. (2003). Visions of 'urban renaissance': the Urban Task Force Report and the Urban White Paper, R. Imrie and M. Raco (ed), Urban Renaissance? New Labour, Community and Urban Policy içinde, The Policy Press, Bristol.
Lundy, L. and McEvoy, L. (2011) 'Children's rights and research processes: Assisting children to (in)formed views', Childhood 19 (1), 129-44.

Macgregor, C. (2010). Urban Regeneration as a Public Health Intervention. Journal of Social Intervention: Theory and Practice 19 (3).

Maginn, P.J. (2007). Towards more effective community participation in urban regeneration: The potential of collaborative planning and applied ethnography, Qualitative Research, 7(1), 25-43.

Mukul, İ and Sarı, S. (2015). Cities as Place of Transformation in Turkey: Urban Transformation. The journal of International Social Research 8 (39), 893-921.

O'Connell, C., O'Sullivan, S. \& Byrne, L. (2015). Children's voices in housing estate regeneration. Available at: http://www.dcya.gov.ie/documents/ Publications/20150617 ChildrensVoicesHousingRegeneration.pdf. Last accessed: November, 23, 2015.

Önder, S., Polat, A \& Korucu, S. (2011). The evaluation of existing and proposed active green spaces in Konya Selçuklu District, Turkey. African Journal of Agricultural Research 6 (3), 738-747.

Özdemir, D. (2010). Kentsel Dönüşümde Politika, Mevzuat, Uygulama. Avrupa Deneyimi. İstanbul Uygulamaları. Ankara: Nobel Yayınları.

Özden P. P. (2008). Kentsel Yenileme. Ankara: İmge Kitapevi

Selltiz, C., Jahoda, M., Deutsch. M \& Cook, S.W. (1963). Research methods in social relations. New York: Holt.

Severcan, Y.C. (2012). Children's attachment to public space in the context of urban regeneration: Effects of children's involvement in planning and design activities. Doctorate Thesis, University of Colorado Denver.

Smith, M. K. (2011).'Neighbourhoods and regeneration. Theory, practice, issues.' The encyclopaedia of informal education.

Speak, S. (2000). Children in urban regeneration: foundations for sustainable participation. Community Development Journal 35, 31-40.

Technical and Environmental Administration Urban Design Department, (2012). Integrated Urban Renewal in Copenhagen, Available at: http:// kk.sites.itera.dk /apps/kk_pub2/pdf/870_hHa1d53AJZ.pdf. Last accessed: August, 16, 2015.

TUIK, Turkish Statistical Institute (2015). Available at: http://www.tuik.gov. tr/PreHaber Bultenleri.do?id=18616. Last accessed: May, 25, 2015.

Turok, I. (2005). Kentsel dönüşüm neler yapılabilir ve nelerden kaçınılmalı. D. Özdemir, P. Özden ve S. Turgut (ed), Uluslararası Kentsel Dönüşüm Uygulamaları Sempozyumu İçinde, 27-30 Kasım 2004, Küçükçekmece Belediyesi Yayınları, İstanbul.

Türkün, A. (2011). Urban Regeneration and Hegemonic Power Relationships. International Planning Studies 16 (1), 61-72.

UN Convention on the Rights of the Child (1989), Available at: http://www. unicef.org. Last accessed: March, 08, 2015.

Ülger, N. E. (2010). Türkiyéde Arsa Düzenlemeleri ve Kentsel Dönüşüm. Ankara: Nobel Yayın Dağııım.

Wells, N.M., Evans, G.W. and Yang, Y. (2010). Environments and health: Planning decisions as public-health decisions. Journal of Architectural and Planning Research 27 (2), 124-143.

Akkoyunlu Ertan, K., Ökmen, M. \& Zeybekoğlu Sadri, S. (2013). “Kentsel dönüşüm ve insan haklari”, Istanbul:Bilgi Üniversitesi Yayınları. 